\title{
Investigating the Levels of Estrdiole, Follicle Stimulating Hormones (FSH), Luteinizing Hormones (LH) and Testosterone in Human Infertility Issue
}

\author{
Hina Zubair ${ }^{1}$, Junaid Zeb ${ }^{2 *}$, Bushra Zubair ${ }^{2}$ and Maham Qazi ${ }^{2}$ \\ ${ }^{1}$ Department of Biochemistry Faculty of Sciences, Pir Mehr Ali Shah Arid Agriculture University, Pakistan \\ ${ }^{2}$ Deptt of Surgery, Teaching Hospital, Pakistan \\ *Corresponding author: Junaid Zeb, Department of Surgery, Post graduate medical institute, Khyber, Teaching Hospital, Peshawar, Pakistan, Tel: \\ 0342-9070725; Email: junaidzeb100@gmail.com
}

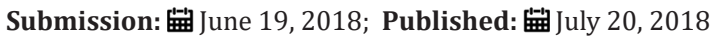

\begin{abstract}
Objectives: To investigate infertility issues in Females and males due to sex hormones imbalance, Estimation of FSH, LH, Estradiol level in females infertile and Testosterone level in infertile males and females.

Methodology: It was a cross sectional study conducted at reproductive physiology/health, public health laboratory division, national institute of health Islamabad from December 2015 to September 2017. Study was carried out on 60 male and 60 female infertile patients. FSH, LH, estradiole were estimated for females and testosterone for males by Immunoenzymatic assay (ELISA). Data was analyzed by SPSS 16.

Results: Biochemical parameters for female population showed that $16.67 \%$ of sampled women indicated FSH level $<4.5-11 \mathrm{mIU} / \mathrm{Ml}$ while $40 \%$ with FSH level $>4.5-11 \mathrm{mIU} / \mathrm{Ml}$ and $43.33 \%$ fall within normal range i.e., $4.5-11 \mathrm{mIU} / \mathrm{Ml}$. In the same manner, $10 \%$ of sampled female population was indicated with $\mathrm{LH}$ levels $<2.12 \mathrm{mlU} / \mathrm{Ml}, 36.57 \%$ with $>10.89 \mathrm{mlU} / \mathrm{Ml}$ and $53.33 \%$ within normal range i.e., $2.12-10.89 \mathrm{mIU} / \mathrm{Ml}$. Similarly, 30\% women showed estradiol levels $<40.7 \mathrm{pg} / \mathrm{ml}$ while $16.67 \%$ were with $>220.4 \mathrm{pg} / \mathrm{ml}$ and $53.33 \%$ were found within normal range i.e., $40.7-220.4 \mathrm{pg} / \mathrm{ml}$. While the most common cause of male infertility by hormonal imbalance is due to either increased or decreased level of testosterone. $36.67 \%$ of sampled males indicated testosterone level less than normal i.e. $<1.68 \mathrm{ng} / \mathrm{ml}$ while $48.33 \%$ with testosterone level $>7.81 \mathrm{ng} / \mathrm{ml}$ and $15.00 \%$ fall within normal range i.e., $1.68-7.81 \mathrm{ng} / \mathrm{ml}$.
\end{abstract}

Conclusion: We concluded from our study that the most common cause of female infertility by hormonal imbalance is due to either increased or decreased level of follicle stimulating hormone (FSH) followed by estradiole and leutinizing hormone (LH). While the most common cause of male infertility by hormonal imbalance is due to either increased or decreased level of testosterone.

Keywords: Estradiol; Follicle stimulating hormone (FSH); Luteinizing hormone (LH) and testosterone hormones; Infertility

\section{Introduction}

Infertility is the inability to conceive after one year of unprotected regular sextual intercourse with same partner. Term infertility means absolute inability to conceive $[1,2]$. So we can generally say if a couple is unable to connive in more than one year are regarded as sub fertile. So in general subfertility is the condition in which the male is unable to conceive after one year of regular unprotected intercourse and had sperm count of $<20$ million/ml [3]. $1^{\text {st }}$ definition quoted in start around $14 \%$ of total couples are sub fertile [1]. Infertility which primarily affects reproductive system affect male and females with equal rates [4]. A lot of females does not have needed awareness of the period of the month in which they are utmost fertile as well as at what time to look for treatment [5].

In addition to low level of awareness and knowledge, innumerable misconceptions and mistaken belief about infertility are also important risk in females around the globe. Female infertility may be in form of inovulation, obstructed fallopian tubes, endometriosis or other uterine abnormalities [6]. Both spermiogenesis in the germinal epithelium besides regulative role of Hypothalamohypophyseo-testicular axis is really delicate. Their modifications grow into ostensible likewise in the decline of fertility [7]. Gonad otropin releasing hormone ( $\mathrm{GnRH}$ ) releases FSH and LH from the pituitary gland which is under negative feedback control of gonads, moreover FSH secretion is controlled by the negative feedback of the testosterone and inhibin, the consequence of a significant oligozoospermia is reduced inhibin synthesis [8]

According a survey of WHO about 8-10\%of couples face various types of infertility. Moreover other researchers have shown this ratio as around 50-80 million people around the globe [9]. Worldwide around 48.5 million couples with unprotected intercourse face in- 
fertility [10]. While Sharlip et al. [11], stated it 15\% with unprotected intercourse [11] Gender wise distribution of infertility due to male factor ranged from $20 \%$ to $70 \%$ and that the percentage of infertile men ranged from $2 \cdot 5 \%$ to $12 \%$ [12].

Absence of preceding pregnancy mean primary infertility is while secondary infertility is when there has been a preceding pregnancy, irrespective of outcome [13]. Testosterone is necessary in maintaining spermatogenesis and male fertility.

Study based evidence gathered recommended that classical and non-classical testosterone signaling donate to the preservation of spermatogenesis and male fertility [14]. Hormonal problems are also included in the significant causes in the assessment of female Infertility. Considerably lower LH, FSH, progesterone and estradiol levels and suggestively higher prolactin level were experiential in the infertile women [15]. Age is predictive for long-term live birth but in combination with the existence of an ovulatory cycle and serum TSH or serum AMH [16]. In general male infertility is not well reported specially where there is gender descriminations [17]. Moreover male infertility has never considered as disease resulting in sparse statistics [18].

In Pakistan occurrence of infertility is $21.9 \%$, primary infertility in $3.9 \%$ while secondary Infertility in $18.0 \%$ [19]. It has got great social implications in our country [20]. The objectives of present study were; to investigate infertility issues in females and males due to sex hormones imbalance, Estimation of FSH, LH, Estradiol level in females infertile and Testosterone level in infertile males and females.

\section{Material and Methods}

A cross sectional study was done with total sample of 120 individuals, 60 males and 60 females with a history of infertility for more than one year were enrolled for the study. Study was carried out at reproductive physiology/health, public health laboratory di- vision, national institute of health Islamabad from December 2015 to September 2017. These patients were referred from different parts of the country for hormones and semen analysis. All included patients had married; age more than 18 years and history of infertility for more than 1 year. Those who had Childs or had history of sexually transmitted disease or pelvic inflammatory diseases were excluded from study. Clinical examination of all the subjects was carried out and information regarding age, health problems was recorded Fasting blood was collected during mid-cycle 14-16 day. Consent of patients was obtained before their enrollment in the study. Data was collected by questionnaire fulfilled by interviewers by asking pre designed question from patients. About $03 \mathrm{ml}$ of venous blood was drawn from the anterior anticubital vein; serum was stored at $-20^{\circ} \mathrm{C}$. FSH, LH, estrogen were estimated for females and testosterone for males by Immunoenzymatic assay (ELISA), using standard kits. Data was analyzed by SPSS 16, for continuous variables Mean \pm SD was calculated while frequency and percentages for categorical.

\section{Results}

Our present data indicates that young age women contribute the most in total population of the study area as $45 \%$ of the sampled population is consisted of women of age ranging from 20-29 years old followed by $36.67 \%$ of $30-39$ years old. Major portion of the population remains at home and pay the household responsibly i.e. $65 \%$. 51.67\% contributed for urban residence as the migration of population from rural areas to cities is widespread phenomenon in the country. Moreover, education rate in the area is desperately low as $25 \%$ of the sampled population is found to be with primary School graduation that is a literacy rate below the average rate for developing country. Male data showed most (36.67\%) patients between age group 20-29 years, 60\% employees and 61.6\% from urban areas while education status showed that most (36.67\%) of infertile male patients were graduate; detail given in Table 1.

Table 1: Anthropometric measurements of male and female.

\begin{tabular}{|c|c|c|c|}
\hline & & $\begin{array}{c}\text { Females } \\
\text { (No. and \% es) }\end{array}$ & $\begin{array}{c}\text { Males } \\
\text { (No. and \% es) }\end{array}$ \\
\hline \multirow{4}{*}{$\begin{array}{l}\text { Age group } \\
\text { (in years) }\end{array}$} & $<20$ & $4(6.67 \%)$ & $11(18.33 \%)$ \\
\hline & $20-29$ & $27(45 \%)$ & $22(36.67 \%)$ \\
\hline & $30-39$ & $22(36.67 \%)$ & $21(35 \%)$ \\
\hline & $40-50$ & $7(11.67 \%)$ & $6(10 \%)$ \\
\hline \multirow{2}{*}{ Occupation } & Government/Private employ & $21(35 \%)$ & $36(60 \%)$ \\
\hline & Household & $39(65 \%)$ & $24(40 \%)$ \\
\hline \multirow{2}{*}{ Residence } & Urban & $31(51.67 \%)$ & $37(61.6 \%)$ \\
\hline & Rural & $29(48.33 \%)$ & $23(38.33 \%)$ \\
\hline
\end{tabular}




\begin{tabular}{|c|c|c|c|}
\hline \multirow{4}{*}{ Educational status } & $<$ Middle & $15(25 \%)$ & $1(1.67 \%)$ \\
\cline { 2 - 4 } & Middle & $14(23.33 \%)$ & $12(20 \%)$ \\
\cline { 2 - 4 } & Matriculation & $13(21.67 \%)$ & $12(20 \%)$ \\
\cline { 2 - 4 } & Graduate & $12(20 \%)$ & $22(36.67 \%)$ \\
\cline { 2 - 4 } & Post graduate & $6(10 \%)$ & $13(21.67 \%)$ \\
\hline
\end{tabular}

Biochemical parameters for female population showed that $16.67 \%$ of sampled women indicated FSH level $<4.5-11 \mathrm{mIU} / \mathrm{Ml}$ while $40 \%$ with FSH level $>4.5-11 \mathrm{mIU} / \mathrm{Ml}$ and $43.33 \%$ fall within normal range i.e., $4.5-11 \mathrm{mIU} / \mathrm{Ml}$. In the same manner, $10 \%$ of sampled female population was indicated with $\mathrm{LH}$ levels $<2.12 \mathrm{mlU} / \mathrm{Ml}$,
$36.57 \%$ with $>10.89 \mathrm{mlU} / \mathrm{Ml}$ and $53.33 \%$ within normal range i.e., 2.12-10.89mIU/Ml, Similarly, 30\% women showed estradiol levels $<40.7 \mathrm{pg} / \mathrm{ml}$ while $16.67 \%$ were with $>220.4 \mathrm{pg} / \mathrm{ml}$ and $53.33 \%$ were found within normal range i.e., $40.7-220.4 \mathrm{pg} / \mathrm{ml}$ detail given in Table 2.

Table 2: Hormones level in female population.

\begin{tabular}{|c|c|c|c|}
\hline \multicolumn{2}{|c|}{ Hormones } & Number (n) & Percentage (\%) \\
\hline \multirow{3}{*}{ FSH level } & $<4.5 \mathrm{IU} / \mathrm{ml}$ & 10 & 16.67 \\
\cline { 2 - 4 } & $4.5-11 \mathrm{IU} / \mathrm{ml}$ & 26 & 43.33 \\
\cline { 2 - 4 } & $>11 \mathrm{IU} / \mathrm{ml}$ & 24 & 40 \\
\hline \multirow{3}{*}{ LH level } & $<2.12 \mathrm{IU} / \mathrm{ml}$ & 6 & 53.33 \\
\cline { 2 - 4 } & $2.12-10.89 \mathrm{IU} / \mathrm{ml}$ & 32 & 36.67 \\
\hline \multirow{2}{*}{ Estradiol } & $>10.891 \mathrm{~J} / \mathrm{ml}$ & 22 & 30 \\
\hline Level & $<40.7 \mathrm{pg} / \mathrm{ml}$ & 18 & 53.33 \\
\hline
\end{tabular}

While data regarding male infertile patients showed that the most common cause of male infertility by hormonal imbalance is due to either increased or decreased level of testosterone. $36.67 \%$ of sampled males indicated testosterone level less than normal i.e. $<1.68 \mathrm{ng} / \mathrm{ml}$ while $48.33 \%$ with testosterone level $>7.81 \mathrm{ng} / \mathrm{ml}$ and $15.00 \%$ fall within normal range i.e., $1.68-7.81 \mathrm{ng} / \mathrm{ml}$ detail given in Table 3.

Table 3: Testosterone levels in sampled male population.

\begin{tabular}{|c|c|c|}
\hline Testosterone Level & Number $(\mathbf{N})$ & Percentage (\%) \\
\hline$<1.68 \mathrm{ng} / \mathrm{ml}$ & 22 & 36.67 \\
\hline $1.68-7.81 \mathrm{ng} / \mathrm{ml}$ & 9 & 15 \\
\hline$>7.81 \mathrm{ng} / \mathrm{ml}$ & 29 & 48.33 \\
\hline
\end{tabular}

\section{Discussion}

The purpose of this study was to investigate the causes of infertility in women due to hormonal imbalance including the estradiole, luteinizing hormone (LH) and follicle stimulating hormone (FSH) as well as in men because of abnormal status of testosterone. The results of the present study showed that that most of infertile females were in age group 20-29 years of age comparable to study done at Jinnah hospital Mianwali found infertility among younger females [21]. We found that common cause of female infertility by hormonal imbalance is due to either increased or decreased level of follicle stimulating hormone (FSH) followed by estradiole and leutinizing hormone (LH). $16.67 \%$ of sampled women indicated FSH level $<4.5-11 \mathrm{mIU} / \mathrm{Ml}$ while $40 \%$ with FSH level $>4.5-11 \mathrm{mIU} /$ $\mathrm{Ml}$ and $43.33 \%$ fall within normal range i.e., $4.5-11 \mathrm{mIU} / \mathrm{Ml}$. Similarly, $30 \%$ women showed estradiol levels $<40.7 \mathrm{pg} / \mathrm{ml}$ while $16.67 \%$ were with $>220.4 \mathrm{pg} / \mathrm{ml}$ and $53.33 \%$ were found within normal range i.e., $40.7-220.4 \mathrm{pg} / \mathrm{ml}$. In the same manner, $10 \%$ of sampled female population was indicated with $\mathrm{LH}$ levels $<2.12 \mathrm{mlU} / \mathrm{Ml}$, $36.57 \%$ with $>10.89 \mathrm{mlU} / \mathrm{Ml}$ and $53.33 \%$ within normal range i.e., $2.12-10.89 \mathrm{mIU} / \mathrm{Ml}$.

Female infertility may present as an ovulation, obstructed fallopian tubes, endometriosis or uterine abnormalities or hormonal imbalance [6]. Hormone levels in infertile women had been evaluated by many researchers. Higher level of FSH and LH is rarely found in infertile women with a proper menstrual cycle but lower concentrations are observed [13].

Leutinizing hormone (LH) is a hormone released by the pituitary gland in response to luteinizing hormone- releasing hormone. It controls the length and sequence of the female menstrual cycle, including ovulation, preparation of the uterus for implantation of a fertilized egg, and ovarian production of both estrogen and progesterone. Theca cells in the ovary respond to LH stimulation by 
secretion of testosterone, which is converted into estrogen by adjacent granulosa cells. In women, ovulation of mature follicles on the ovary is induced by a large burst of LH secretion - the preovulatory LH surge. Residual cells within ovulated follicles proliferate to form corpora lutea, which secrete the steroid hormones - progesterone and estradiol. Progesterone is necessary for the maintenance of pregnancy, and, in most mammals, LH is required for continued development and function of corpora lutea. When the cut-off level of LH is $>1.5 \mathrm{IU} / \mathrm{L}$, reduction in fertilization and clinical pregnancy rates is observed [22].

Follicle stimulating hormone is also released and synthesized by the anterior pituitary gland. It regulates the body's development, growth and maturation. It also regulates reproductive processes. FSH works alongside with LH. FSH signals some of the follicles in the ovary to begin maturing in preparation for ovulation [23].

Estradiol is produced primarily by the follicles and corpus luteum in the ovaries. This estrogen is the most potent and abundant. Estrogen is essential for healthy bone formation, healthy gene expression, maintaining healthy cholesterol levels, and formation of secondary sexual characteristics [24]. Hyperprolactinemia and low levels of LH, FSH and progesterone may cause anovulation and hence infertility. Both LH and FSH are required for follicle development and oestrogen production hence low levels of these hormones may mean that fewer numbers of follicles will develop and there will be no Graffian follicle formation. Normally as follicles develop, estrogen levels rise which helps to stimulate the endometrium [10]. Rapid advances in understanding this axis occurred because of the development of highly sensitive assays to detect levels of the gonadotropins, estradiole, follicle stimulating hormone (FSH) and luteinizing hormone (LH), testosterone and other sexual hormones which are either absent or barely detectable in hypogonadotropic hypogonadism [25].

The results of the present study showed that the most common cause of male infertility by hormonal imbalance is due to either increased or decreased level of testosterone. $36.67 \%$ of sampled males indicated testosterone level less than normal i.e. $<1.68 \mathrm{ng} / \mathrm{ml}$ while $48.33 \%$ with testosterone level $>7.81 \mathrm{ng} / \mathrm{ml}$ and $15.00 \%$ fall within normal range i.e., $1.68-7.81 \mathrm{ng} / \mathrm{ml}$ Testosterone is produced by leydig cells present in the interstitial space of the testis between the seminiferous tubules and then diffuses into the tubules. Because testosterone is produced locally by the Leydig cells, the levels of testosterone in men are 25 to 125-fold higher in the testis (340$2000 \mathrm{nM})$ as compared to the serum (8.7-35nM). The reduction of testicular testosterone levels after hypophysectomy, immune neutralization of LH, administration of anti androgens or destruction of Leydig cells results in the detachment of developing spermatids (step 8-19 spermatids) from the sertoli cell and the halting of spermatogenesis during the process of meiosis [14].

\section{Conclusion}

Infertility is a multidimensional health issue. Numerous medical conditions can contribute to infertility. In fact, most cases of infertility are due to hormonal imbalance disorders. We concluded from our study that the most common cause of female infertility by hormonal imbalance is due to either increased or decreased level of follicle stimulating hormone (FSH) followed by estradiole and leutinizing hormone (LH). While the most common cause of male infertility by hormonal imbalance is due to either increased or decreased level of testosterone. Only little percentage of infertile male patients in our study had testosterone level in normal range.

\section{References}

1. Khan MS, Ali I, Hassan M, Nawaz K, Zeb M, et al. (2007) Determination of serum gonadotropin and testosterone levels in male infertility. J Postgrad Med Inst 21(2): 86-91.

2. Turek PJ (2008) Male infertility. In: Tanagho EA, Mc Aninch JW (Eds.), (17 $7^{\text {th }}$ edn) Smith's general urology, Mc Graw-Hill Companies, New York, USA, pp. 684-717.

3. Wong WY, Thomas CM, Merkus JM, Zielhuis GA, Steeqeers-Theunissen RP (2000) Male factor sub fertility: Possible causes and the impact of nutritional factors. Fertil Steril 73(3): 435-442.

4. Sohrabvand F, Jafarabadi M (2005) Knowledge and attitudes of infertile couples about assisted reproductive technology. Int J Repord Biomed 3(2): 90-94.

5. Adashi EY, Cohen J, Hamberger L, Jones HW, de Kretser DM, et al. (2005) Public perception on infertility and its treatment: an international survey. The Bertarelli Foundation Scientific Board. Hum Reprod 15(2): 330-334.

6. Foster WG, Neal MS, Han MS, Dominguez MM (2008) Environmental contaminants and human infertility, hypothesis or cause for concern. J Toxicol Environ Health B Crit Rev 11(3-4): 162-176.

7. Martini F, Ober WC (2001) Fundamentals of anatomy \& physiology. ( $5^{\text {th }}$ edn), Upper Saddle River, Prentice Hall, New Jersey, USA.

8. Anderson RA, Wallac EM, Groome NP, Bellis AJ, Wu FC (1997) Physiological relationships between inhibin $\mathrm{B}$, follicle stimulating hormone secretion and in normal men and response to gonadotrophin suppression b exogenous testosterone. Hum Reprod 12(4): 746-747.

9. Gnoth C, Godehardt E, Frank-Herrmann P, Friol K, Tigges J, et al. (2005) Definition and prevalence of subfertility and infertility. Hum Reprod 20(5): 1144-1147.

10. Martinez G, Daniels K, Chandra A (2012) Fertility of men and women aged 15-44 years in the United States: National Survey of Family Growth, 2006-2010. Natl Health Stat Report 12(51): 1-28.

11. Sharlip ID, Jarow JP, Belker AM, Lipshultz LI, Sigman M, et al. (2002) Best practice policies for male infertility. Fertil Steril 77(5): 873-882.

12. Agarwal A, Mulgund A, Hamada A, Chyatte MR (2015) A unique view on male infertility around the globe 13: 37.

13. EdmondsI D, Cooke JD (1999) Infertility. In: Whitefield CR (Edr.), $\left(6^{\text {th }}\right.$ edn) Dewhurst's obstetrics and gynaecology for post graduates. Blackwell Sciences, Oxford, India, PP. 432-440.

14.William HW (2010) Non-classical actions of testosterone and spermatogenesis. Philos Trans R Soc Lond B Biol Sci 365(1546): $1557-$ 1569.

15. Olooto WE, Adeleye O, Amballi AA, Mosuro AO (2012) Pattern of reproductive hormones (follicle stimulating hormone, luteinizing hormone, estradiol, progesterone, and prolactin) levels in infertile women in Sagamu South Western Nigeria. Pharm Lett 4(2): 549-553.

16. Murto T, Bjuresten K, Landgren BM, Stavreus-Evers A (2013) Predictive value of hormonal parameters for live birth in women with unexplained infertility and male infertility. Reprod Biol Endocrinol 11: 61. 
17. http://newint.org/features/1998/07/05/infertility/

18. Mascarenhas MN, Flaxman SR, Boerma T, Vanderpoel S, Stevens GA (2012) National, regional, and global trends in infertility prevalence since 1990: a systematic analysis of 277 health surveys. PLoS Med 9: e1001356.

19. Hakim A, Sultan M (2001) Pakistan reproductive health and family planning survey 2000-01. Preliminary Report National Institute of Population Studies Islamabad, Pakistan.

20. Khan MS, Rafat Ullah, Tahir F, Ashraf M, Sajjad M (2012) Seminal volume in the investigation of male infertility. Journal of the College of Physicians and Surgeons Pakistan 22(3): 159-162.

21. Butt ZN, Khan GH (2009) Study of infertility in females by laparoscopy in Remote Area. Journal of Rawalpindi Medical College (JRMC) 13(2): 89-91.
22. Kumar P, Sait SF (2011) Luteinizing hormone and its dilemma in ovulation induction. J Hum Reprod Sci 4(1): 2-7.

23. Gleicher N, Weghofer A, Barad DH (2010) Discordances between follicle stimulating hormone (FSH) and anti-Mullerian hormone (AMH) in female infertility. Reprod Biol Endocrinol 8: 64.

24. Srouji SS, Mark A, Levine Z, Betensky RA, Hornstein MD (2005) Predicting in vitro fertilization live birth using stimulation day 6 estradiol, age, and follicle-stimulating hormone. Fertil Steril 84(3): 795-797.

25. Matzuk MM, Lamb DJ (2008) The biology of infertility: research advances and clinical challenges. Nat Med 14(11): 1197-1213.
Creative Commons Attribution 4.0 International License

For possible submissions Click Here

\section{Submit Article}

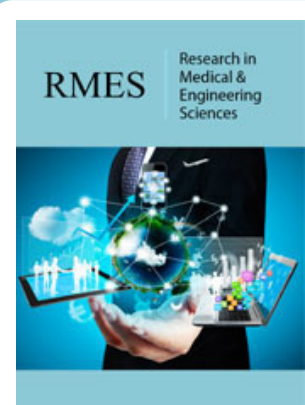

Research in Medical \& Engineering Sciences

\section{Benefits of Publishing with us}

- High-level peer review and editorial services

- Freely accessible online immediately upon publication

- Authors retain the copyright to their work

- Licensing it under a Creative Commons license

- Visibility through different online platforms 